\title{
Glucolipotoxicity of the Pancreatic Beta Cell
}

\author{
Vincent Poitout ${ }^{a, b}$, Julie Amyot ${ }^{b}$, Meriem Semache ${ }^{b}$, Bader Zarrouki ${ }^{a}$, Derek Hagman ${ }^{a}$, and \\ Ghislaine Fontés ${ }^{a}$ \\ a Montreal Diabetes Research Center, CRCHUM and Department of Medicine, University of \\ Montreal, Montreal, QC, Canada \\ b Montreal Diabetes Research Center, CRCHUM and Department of Biochemistry, University of \\ Montreal, Montreal, QC, Canada
}

\section{Summary}

The concept of glucolipotoxicity refers to the combined, deleterious effects of elevated glucose and fatty acid levels on pancreatic beta-cell function and survival. Significant progress has been made in recent years towards a better understanding of the cellular and molecular basis of glucolipotoxicity in the beta cell. The permissive effect of elevated glucose on the detrimental actions of fatty acids stems from the influence of glucose on intracellular fatty-acid metabolism, promoting the synthesis of cellular lipids. The combination of excessive levels of fatty acids and glucose therefore leads to decreased insulin secretion, impaired insulin gene expression, and beta-cell death by apoptosis, all of which probably have distinct underlying mechanisms. Recent studies from our laboratory have identified several pathways implicated in fatty-acid inhibition of insulin gene expression, including the extracellular-regulated kinase (ERK1/2) pathway; the metabolic sensor Per-Arnt-Sim kinase (PASK); and the ATF6 branch of the unfolded protein response. We have also confirmed in vivo in rats that the decrease in insulin gene expression is an early defect which precedes any detectable abnormality in insulin secretion. While the role of glucolipotoxicity in humans is still debated, the inhibitory effects of chronically elevated fatty acid levels has been clearly demonstrated in several studies, at least in individuals genetically predisposed to developing type 2 diabetes. It is therefore likely that glucolipotoxicity contributes to beta-cell failure in type 2 diabetes as well as to the decline in beta-cell function observed after the onset of the disease.

\section{Keywords}

Fatty acids; Glucose; Islet of Langerhans; Diabetes; Insulin

\section{Introduction}

Over the last 20 years, the central role of pancreatic beta-cell dysfunction in the development of type 2 diabetes has become increasingly appreciated [1]. It is now generally accepted that when insulin resistance develops in response to environmental cues such as obesity, a subset of genetically predisposed individuals fails to adequately compensate for the increased insulin demand, and beta-cell failure ensues [2]. In addition, longitudinal studies in humans have

Corresponding author: Vincent Poitout, DVM, PhD, CRCHUM, Technopole Angus, 2901 Rachel Est, Montreal, QC, H1W 4A4, Canada, Tel: +1 514 890-8000 ext. 23603, Fax: +1 514 412-7648, Vincent.poitout@ umontreal.ca.

Publisher's Disclaimer: This is a PDF file of an unedited manuscript that has been accepted for publication. As a service to our customers we are providing this early version of the manuscript. The manuscript will undergo copyediting, typesetting, and review of the resulting proof before it is published in its final citable form. Please note that during the production process errors may be discovered which could affect the content, and all legal disclaimers that apply to the journal pertain. 
clearly demonstrated that beta-cell function deteriorates during the years following diagnosis of type 2 diabetes, regardless of the therapeutic regimen [3,4]. Although the cause of this metabolic deterioration is unknown, several hypotheses have been proposed. Amongst them, chronic hyperglycemia (glucotoxicity [5]), chronic dislipidemia (lipotoxicity [6]), or the combination of both (glucolipotoxicity [7]), have been postulated to contribute to the worsening of beta-cell function over time, creating a vicious cycle by which metabolic abnormalities impair insulin secretion, which further aggravates metabolic perturbations, and so on. While elevated levels of glucose or fatty acids can, by themselves, be demonstrated to have detrimental effects on beta-cell function in many experimental systems, the combination of both nutrients is synergistically harmful, which has led to the concept of glucolipotoxicity $[7,8]$. However, despite years of investigation and significant progress made in the discovery of the underlying molecular and cellular mechanisms of glucolipotoxicity, its contribution to beta-cell failure in type 2 diabetes remains debated. We speculate that this uncertainty stems from several reasons. First, by nature of their long-term design, experiments to test cause-andeffect relationships between chronic metabolic perturbations and functional outcomes are plagued with confounding variables, and therefore difficult to interpret. Second, the inherent limitations of in vivo models have prompted the development of many in vitro systems to test the hypothesis and define its underlying mechanisms. As further discussed in this review, these systems also have important caveats. Third and perhaps most importantly, there is no clear consensus on the definition of the term glucolipotoxicity. While its root (toxicity) implies the presence of cell death, it is often employed more loosely to refer to the functional effects of the combination of high glucose and elevated lipids on the beta cell, for instance on insulin secretion or gene expression. Also, while the concept of glucolipotoxicity implicitly refers to a chronic situation, the notion of chronicity is variable, spanning from a few hours of ex vivo cell culture to many years in diabetic patients. This is particularly problematic since fatty acids have a dual and time-dependent effect on beta-cell function, acutely stimulatory but chronically inhibitory. Thus, there are virtually as many definitions of the term glucolipotoxicity as groups studying it, which has created confusion in the field. For the purpose of this article, we propose to define glucolipotoxicity as the combined, deleterious effects of elevated glucose and fatty acid levels on pancreatic beta-cell function and/or survival. This review focuses on recent developments in the field of glucolipotoxicity from both in vitro and in vivo studies.

\section{Cellular and molecular mechanisms of glucolipotoxicity in the beta cell}

Considering the complexity of designing mechanistic studies in vivo to investigate the chronic effects of fuel oversupply, a number of in vitro models, using insulin-secreting cells and isolated islets, have been employed to identify the cellular and molecular basis of glucolipotoxicity. In these systems, prolonged exposure to elevated levels of fatty acids is associated with inhibition of glucose-induced insulin secretion [9-12], impairment of insulin gene expression [13-18], and induction of cell death by apoptosis [19-28]. Importantly, several of these studies have provided evidence that lipotoxicity only occurs in the presence of concomitantly elevated glucose levels $[15,16,28]$, an observation also confirmed in vivo [29, 30]. The biochemical basis for this permissive effect of glucose will be discussed first in this section, followed by a review of the mechanisms underlying the functional manifestations of glucolipotoxicity on the beta cell (insulin secretion, insulin gene expression, and cell survival).

\section{A. Biochemical pathways and lipid intermediates implicated in glucolipotoxicity}

The permissive effect of glucose on the deleterious actions of chronic fatty acids stems from its influence on intracellular metabolism of fatty acids [31,32]. Prentki and Corkey [7] first proposed that glucose determines fatty acid partitioning in pancreatic beta cells (Figure 1). At low glucose concentrations, fatty acids are transported into the mitochondria via the enzyme carnitine-palmitoyl transferase-1 (CPT-1) for beta-oxidation, which has essentially no 
functional consequences. In contrast, when both glucose and fatty acid concentrations are elevated, intracellular metabolism of glucose leads to the formation of cataplerotic signals, such as citrate, and the generation of malonyl-CoA in the cytosol. Since fatty-acid synthase activity is lower than that of acetyl-CoA carboxylase in the beta cell [33], the predominant effect of malonyl-CoA is to inhibit CPT-1 activity, which in turn blocks fatty acid oxidation and leads to accumulation of long-chain acyl-CoA esters (LC-CoA) in the cytosol [7].

Accumulation of cytosolic LC-CoA, either directly or via generation of lipid-derived signals, adversely affects beta-cell function [8]. In addition to its metabolic effects directing fatty-acid partitioning into esterification, glucose coordinately activates the expression of genes involved in lipogenesis [34]. A key player in this mechanism is the enzyme AMP-activated protein kinase (AMPK), acting as a metabolic sensor that directs the beta cell into a "storage mode" in the face of nutrient oversupply [35], as it does in myocytes and hepatocytes [36]. Indeed, AMPK activity is inversely correlated with the glucose concentration [37] and is stimulated by palmitate [38] in beta cells. Downstream of AMPK, the transcription factor sterolregulatory-element-binding-protein-1c (SREBP1c), which regulates the expression of genes controlling fatty acid synthesis [39], translates the metabolic signal sensed by AMPK into changes in gene expression, leading to enhanced lipogenesis. Glucose also increases the expression of liver X receptor (LXR) which then contributes to enhancing SREBP1c expression and lipid synthesis [40].

While it is now generally accepted that fatty acid partitioning towards esterification and cellular lipid synthesis underpins the cellular mechanisms of glucolipotoxicity in pancreatic beta-cells, the nature of the lipid-derived metabolites directly responsible for the deleterious effects of fatty acids is still elusive. It is unlikely that triglyceride accumulation itself might be the culprit, since triglycerides represent a relatively innocuous form of fat storage that can actually protect against lipotoxicity [41]. Studies have shown that monounsaturated fatty acids are less toxic and can actually protect from the detrimental effects of unsaturated fatty acids because they are more readily esterified into triglycerides [26,41]. Consistent with this notion is the observation that stearoyl CoA desaturase-1 (SCD1) protects from lipoapoptotic cell death induced by palmitate [42]. In fact, whereas deletion of SCD1 in mice improves insulin sensitivity [43], when introduced on the obese, leptin-deficient $o b / o b$ background the SCD1 deletion leads to a worsening of diabetes associated with triglyceride and cholesterol overload in islets [44].

Prentki and colleagues $[45,46]$ have proposed the elegant concept that increased glycerolipid/ fatty acid cycling represents a mean by which the beta cell attempts to protect itself from nutrient oversupply while remaining fuel-responsive so as to be capable of releasing insulin in the face of increased demand. In turn, the unintended consequence of this fuel detoxification mechanism is the generation of harmful intermediates from increased flux through the cycle. The question remains that if triglyceride accumulation is merely a marker of enhanced esterification flux but does not cause glucolipotoxicity by itself, then what are the lipid-derived molecules directly responsible for the impairment of beta-cell function? The role of intermediates of the esterification pathway (e.g. lysophosphatidic acid, phosphatidic acid, diacylglycerols) has been suggested [2] but, to our knowledge, not formally demonstrated. De novo synthesis of ceramide has been shown to play a role both in fatty acid-induced beta-cell death [47] and fatty acid-inhibition of insulin gene expression [17], but not in the impairment of insulin secretion [48]. These observations illustrate an important point, which may in part explain why the lipid-derived intermediates mediating glucolipotoxicity have remained elusive: the mechanisms underlying the various functional manifestations of glucolipotoxicity are likely distinct. For example, accumulation of ceramide impairs insulin gene expression and, under certain circumstances, induces cell death, without affecting insulin secretion. Therefore, our view is that the full array of functional defects associated with glucolipotoxic 
conditions is due to the generation of several intracellular metabolites acting on various signaling pathways and cellular functions rather than to a single intermediate.

While most studies investigating the mechanisms of glucolipotoxicity in the beta cell have focused on the esterification pathway and triglyceride synthesis, cholesterol metabolism has recently been shown to also play an important role. Exposure of beta cells to oxidized lowdensity lipoproteins (LDL) induces apoptosis [49] and decreases insulin gene expression [50], whereas native LDL particles have no effect and high-density lipoproteins (HDL) are protective. Beta-cell specific knock-out (KO) of the ATP-binding cassette transporter subfamily A member 1 (ABCA1), which mediates reverse cholesterol efflux, results in increase cellular cholesterol content and impaired insulin secretion downstream of glucose metabolism, probably at the level of insulin exocytosis [51]. In addition, the ability of the thiazolidinedione rosiglitazone to improve glucose tolerance in high-fat diet fed mice requires a functional ABCA1 in beta cells [51]. Finally, forcing cholesterol synthesis in beta cells by transgenic overexpression of SREBP2 under the rat insulin promoter results in a severe loss of beta-cell mass and a diabetic phenotype [52]. Since LXR regulates ABCA1 expression [51] and is itself directly regulated by glucose [53], glucose therefore coordinately increases fatty acid esterification and intracellular cholesterol synthesis.

The premise to the hypotheses described above that intermediates generated during triglyceride or cholesterol synthesis are mechanistically involved in glucolipotoxicity is that extracellular fatty acids are first transported across the plasma membrane and act intracellularly. This concept has been challenged by the deorphanization of the G-protein coupled receptor GPR40 $[54,55]$. GPR40 is specifically expressed in pancreatic beta cells and is activated by long-chain fatty acids, which raises the possibility that some of the functional effects of fatty acids on the beta-cell might be mediated by activation of a cell-surface receptor. Consistent with this possibility, a role for GPR40 in mediating fatty acid-inhibition of insulin secretion has been suggested by the observation that islets from GPR40 KO mice are insensitive to the inhibitory effects of prolonged fatty acids [56]. Using a different line of GPR40 KO mice, we were unable to reproduce these findings and found that deletion of the receptor does not protect islets from fatty acid-inhibition of glucose-induced insulin secretion [57]. In addition, subsequent studies also using whole-body KO found that GPR40 deletion did not protect mice from high-fat dietinduced glucose intolerance [58,59]. This conclusion was further supported by the observation that small molecule GPR40 agonists improved glucose tolerance in mice with high-fat dietinduced obesity [60]. Therefore, we do not favor the view that GPR40 plays a major role in the mechanisms of glucolipotoxicity in the beta cell.

\section{B. Mechanisms underlying the functional manifestations of glucolipotoxicity}

1. Fatty-acid impairment of insulin secretion-Prolonged exposure of beta cells to fatty acids in vitro inhibits glucose-stimulated insulin secretion [9-12], a phenomenon also observed in vivo in rats [61] and humans [62]. In recent years, several potential mechanisms have been investigated, including upregulation of uncoupling protein 2 (UCP2), activation of the novel isoform of protein kinase $\mathrm{C} \mathrm{PKC} \varepsilon$, and late exocytotic events.

UCP2 is a ubiquitously expressed mitochondrial carrier which has been suggested to uncouple the respiratory chain from ATP synthesis [63], although its biological functions are still unclear [64]. Initial evidence suggested that UCP2 might modulate insulin secretion and thereby play a role in glucolipotoxicity. This was based on the observations that increasing UCP2 expression in beta cells impairs insulin secretion $[65,66]$ and that UCP2 KO animals on a mixed genetic background have increased circulating insulin levels and are protected from diabetes [63,67]. This contention has been recently challenged by the observation that KO of UCP2 on 3 different congenic backgrounds in the mouse leads to oxidative stress and impaired insulin secretion [68]. Thus, the increase in UCP2 expression observed in islets after high-fat feeding in rodents 
$[30,66]$ or exposure to fatty acids in vitro $[69,70]$ likely represents a cellular defense mechanism against fuel overload and oxidative stress rather than a deleterious response. Consistent with this possibility is the observation that transgenic overexpression of UCP2 does not alter mitochondrial function or glucose-induced insulin secretion but decreases reactive oxygen species production [71]. Overall, it appears unlikely that an increase in UCP2 expression in response to fatty acids represents a causal mechanism of the impairment of insulin secretion under glucolipotoxic conditions.

Activation of the lipid-regulated isoform PKC $\varepsilon$ has also been suggested as a possible candidate signaling molecule underlying the decrease in insulin secretion in glucolipotoxicity. Work by the group of Biden has shown that the normalization of glucose tolerance in PKC $\varepsilon$ KO mice under high-fat feeding was due to improved insulin secretion [72]. Further, they demonstrated that islets isolated from PKC $\varepsilon$ knockout mice were protected from the deleterious effects of fatty acids on insulin secretion in vitro, and that inhibition of PKC $\varepsilon$ was capable of restoring insulin secretion in islets from $d b / d b$ mice [72]. More recently, this group has shown that the improvement in insulin secretion in PKC $\varepsilon$ knock-out islets in the face of glucolipotoxicity was due to selective restoration of the amplifying pathway of insulin release, probably due to the generation of a lipolytic intermediate [73]. Interestingly, this is consistent with the concept proposed by Prentki and colleagues that lipolysis-generated signals contribute to the regulation of insulin secretion [74] and that, more generally, glycerolipid/fatty acid cycling in the beta cell provides essential coupling factors for insulin secretion but becomes detrimental under conditions of fuel oversupply [45,46].

Finally, evidence suggests that fatty acids might alter one or more late steps of insulin exocytosis in beta cells. Kato et al. [75] have shown that expression of granuphilin, an effector of the small GTP-binding protein Rab27a, which plays a key role in the docking of insulin secretory granules to the plasma membrane, is increased in islets exposed to palmitate as a consequence of upregulation of SREBP1c. This in turn inhibits insulin secretion in response to fuel and non-fuel stimuli. In addition, Olofsson et al [76] demonstrated that prolonged exposure of mouse islets to glucose and fatty acids inhibited insulin secretion at a very late stage of exocytosis by interfering with the release of insulin at the fusion pore. These findings suggest that the mechanisms by which fatty acids affect insulin secretion might, at least in part, lie at the level of the exocytotic machinery and, consequently, impair insulin secretion in response not only to glucose but also to other secretagogues.

2. Fatty-acid impairment of insulin gene expression-We $[15-18,77]$ and others $[13,14]$ have shown that prolonged exposure to fatty acids impairs insulin gene expression in the presence of high glucose. The mechanisms whereby fatty acids affect insulin gene expression are distinct from those by which they impair insulin secretion. First, whereas both palmitate and oleate inhibit insulin secretion, only palmitate affects insulin gene expression [48]. This is due to the fact that only palmitate can serve as a substrate for de novo ceramide synthesis [17]. The transcriptional mechanisms by which palmitate inhibits insulin gene expression do not involve changes in insulin mRNA stability but, rather, inhibition of glucoseinduced insulin promoter activity [17]. This is associated with decreased binding activity of the transcription factors pancreas-duodenum homeobox 1 (PDX-1) and MafA [18]. PDX-1 is affected in its ability to translocate to the nucleus, whereas MafA is affected at the level of its expression [18]. This is in contrast to the mechanisms of glucotoxicity, which involve posttranslational modifications of MafA [78].

The mechanisms whereby ceramide generation from palmitate impairs PDX-1 subcellular localization and MafA expression are unknown, although recent studies have identified potential candidates. The c-jun NH2-terminal kinase JNK is a known target of ceramide [79] and can repress insulin gene transcription both via c-jun-dependent inhibition of E1-mediated 
transcription [80,81] and c-jun independent inhibition of PDX-1 binding [82]. In addition, Solinas et al. [83] have shown that palmitate activates JNK in beta cells and that the resulting phosphorylation of insulin receptor substrates 1 and 2 at sites that impair insulin signaling decreases insulin gene transcription.

Recent studies in our laboratory have also attempted to identify the signaling mechanisms implicated in palmitate inhibition of insulin gene expression. First, we have shown that palmitate enhances glucose-induced phosphorylation of the extracellular-regulated kinases (ERK) $1 / 2$, and that pharmacological inhibition of ERK1/2 partially restores insulin gene expression in insulin-secreting cells and isolated islets exposed to palmitate or ceramide [84]. Second, we have observed that palmitate blocks the induction of the Per-Arnt-Sim kinase (PASK) [84]. PASK is an evolutionarily conserved serine/threonine protein kinase, containing a PAS domain sensitive to the intracellular environment which regulates the kinase domain to transduce the signal [85]. In budding yeast, it coordinates sugar storage and protein synthesis with carbohydrate availability [86]. In mammals, it has been demonstrated to be an important regulator of glycogen synthase and cellular energy balance [87]. In pancreatic beta cells, PASK is required for glucose-induced insulin gene transcription [88]. In our recent study [84], we observed that overexpression of PASK prevents the inhibitory effect of palmitate on insulin mRNA and PDX-1 mRNA and protein expression in MIN6 cells. In addition, adenoviralmediated overexpression of wild-type PASK increased, whereas a kinase dead mutant of PASK acting as a dominant negative decreased, insulin mRNA and PDX-1 protein expression in islets. Interestingly, the PASK pathway appears to be independent from the ERK1/2 pathway and to have no effect on MafA expression in our system, suggesting that at least 3 independent signalling arms contribute to the overall decrease in insulin gene expression [84] (Figure 2). Although our initial study revealed that palmitate mostly affects PDX-1 in its subcellular localization rather than its whole-cell expression levels [18], overexpression of a kinase dead mutant of PASK also reduces PDX-1 mRNA levels. This suggests that reduction of PDX-1 expression might also contribute to decreasing its binding activity under glucolipotoxic conditions. Whether PASK can directly phosphorylate PDX-1 and, thereby, alter its nuclear translocation is unknown and currently under investigation. Recently, expression the CAAT enhancer-binding protein $\beta(\mathrm{C} / \mathrm{EBP} \beta)$, a negative regulator of insulin gene transcription [89] has been shown to increase in beta cells in response to fatty acids [90]. Interestingly, we also observed a marked increase in C/EBP $\beta$ mRNA levels upon overexpression of the dominantnegative PASK mutant in MIN6 cells [84]. This raises the possibility that, as demonstrated under glucotoxic conditions [91], C/EBP- $\beta$ binds to the transcription factor nuclear factor of activated T cells (NFAT) on the insulin promoter and thereby inhibits MafA binding activity.

A role for the unfolded protein response (UPR) and endoplasmic reticulum (ER) stress in betacell failure has received considerable attention in the past few years, in part because the beta cell's intense secretory activity makes it particularly susceptible to perturbations of ER homeostasis [92]. As discussed in more details in the next section, markers of ER stress have been shown to be induced by prolonged exposure to fatty acids in several studies [93-101]. In most cases, the strong induction of ER stress markers in response to fatty acids is associated with apoptosis. Under our culture conditions of isolated rat islets in the presence of glucose and palmitate, which are not associated with significant cell death [84,102], we have not been able to detect any activation of the inositol requiring ER-to-nucleus signal kinase (IRE) or protein kinase R-like ER kinase (PERK) branches of the UPR (unpublished data). In contrast, we have observed cleavage of the transcription factor ATF6 under these conditions. Since ATF6 is a negative regulator of insulin gene transcription [103], these preliminary results led us to hypothesize that an early activation of the ATF6 branch of the unfolded protein response upon exposure to fatty acids might represent a protective mechanism whereby the beta cell attempts to further decrease the load to the ER by inhibiting insulin gene expression. This would occur as part of the unfolded protein response, before overt ER stress and associated 
apoptosis develops. In later stages of more severe ER stress associated with cell death, it is possible that alterations in PDX-1 function [96,104] or insulin mRNA stability [105] also contribute to the decrease in insulin gene expression.

Overall, available data regarding the mechanisms of fatty-acid inhibition of the insulin gene reveal a complex picture which appears to involve several independent pathways that all concur to decrease its expression, which is an early, and possibly protective, response of the beta cell in the face of nutrient oversupply (Figure 2). Importantly, the decrease in insulin gene expression under glucolipotoxic conditions is also observed in vivo ([77]; see section III below).

3. Fatty acid induction of beta-cell death-Saturated fatty acids can induce beta-cell death by apoptosis in the presence of high glucose $[22,26,28]$, whereas unsaturated fatty acids are usually protective $[21,22,28]$. As mentioned above, this difference is likely due to the greater ability of unsaturated fatty acids to form intracellular triglycerides [21,41,42]. Several mechanisms have been implicated, including ceramide formation [20,23,26,47], oxidative stress [25,27,106,107], and inflammation [108]. Recently, as mentioned above considerable evidence has been provided in support of a role for the UPR and ER stress in saturated fattyacid induced cell death ([93-101] and reviewed in [59]). The mechanisms by which saturated fatty acids such as palmitate induce ER stress are thought to involve depletion of ER calcium stores [99,101] and result in the activation of JNK [99,100], although JNK activation can, under some conditions, be detected prior to the appearance of ER stress [98]. Interestingly, palmitate was shown to induce a rapid degradation of carboxypeptidase E, which resulted not only in altered proinsulin maturation, but also in ER stress and apoptosis [109]. The changes in CPE levels were demonstrated to occur prior to the development of any sign of ER stress, and to require palmitate metabolism and calcium influx, although the precise mechanisms by which palmitate initiates CPE degradation remain to be clarified [109]. Of note, however, a study by Lai et al. [110] using insulin-secreting cells and isolated islets provided evidence that palmitateinduced apoptosis can also occur in the absence of detectable ER stress. Finally, markers of ER stress are increased in pancreatic sections of type 2 diabetic patients [111].

These observations raise the question as to whether fatty-acid induced apoptosis in beta cells is primarily mediated by ER stress or the mitochondrial death pathway. Intrinsic defects in mitochondrial function have been well documented under conditions of nutrient overload [112], and perturbations in mitochondrial permeability are observed early in the development of fatty-acid induced cell death in beta cells [113]. Luciani et al. [114] have recently shown that depletion of ER calcium stores under conditions of ER stress can lead secondarily to mitochondrial dysfunction, suggesting that perhaps under glucolipotoxic conditions ER stress is a primary event which leads to triggering of several proapoptotic pathways, including mitochondrial-mediated cell death.

Finally, a recent study by Lovis et al. [115] has shown that increased expression of the microRNAs miR34a and miR146 also contributes directly to palmitate-induced cell death in insulin-secreting cells and isolated islets, and the overall role of microRNAs in glucolipotoxicity will hopefully become clearer as progress towards understanding their implications in beta-cell function continues to be made.

\section{Limitations of in vitro studies of glucolipotoxicity}

While in vitro models using insulin-secreting cells and isolated islets have proven extremely valuable in dissecting the cellular and molecular mechanisms of glucolipotoxicity, they also have significant limitations which should be borne in mind when interpreting the results obtained in these systems. First, there appears to be species-related differences in the sensitivity to fatty acid-induced cell death [110]. For instance, whereas a 24-h exposure of human islets 
to elevated glucose and palmitate is sufficient to observe apoptosis [28], we have not detected any cell death in rat islets after $72 \mathrm{~h}$ of culture under similar conditions $[17,48,84]$. Second, the concentrations of fatty acids used in vitro vary amongst publications. The key determinant of fatty acid potency is the fraction that is unbound to BSA, which depends on the molar ratio of fatty acids to albumin as well as the mode of preparation. Using a fluorescent probe that specifically measures the unbound fraction of fatty acids [116], we observed that when palmitate at a total concentration of $0.5 \mathrm{mM}$ was pre-complexed to bovine serum albumin with a molar ratio of fatty acid:albumin of 5:1, the unbound concentration is in the range of $200 \mathrm{nM}$ (Figure 3), which represents approximately 3 times the unbound concentration measured in the plasma of lean individuals by the same method [117]. Finally, the concentrations of fatty acids in the vicinity of the beta-cells in vivo are unknown and are probably determined by several different factors, including the activity of lipoprotein lipase, which accounts for some of the local delivery of fatty acids to the cells [118]. In fact, it is likely that lipoprotein lipase activity is an important control point for fatty acid delivery to beta-cells, since both beta-cell specific deletion and overexpression of its gene in the mouse impairs glucose homeostasis and insulin secretion [119]. Thus, the results of in vitro experiments using fatty acids should be interpreted with caution, particularly when marked cytotoxicity is observed.

\section{In vivo studies}

\section{A. Rodent models of glucolipotoxicity}

For the reasons described above, the findings of in vitro studies should be confirmed in vivo before they can be extrapolated to physiological or pathological situations. In this regard, pioneering studies by the group of Unger in the Zucker Diabetic Fatty (ZDF) rat were instrumental in establishing the concept of lipotoxicity and identifying some of its basic mechanisms (reviewed in [120]). In particular, these studies first identified the key role for ceramide as an intracellular mediator of glucolipotoxicity. Thus, in this model accumulation of intra-islet ceramide is detected prior to beta-cell dysfunction [121] and inhibition of ceramide synthesis prevents beta-cell death [47]. In more recent studies the beneficial effects of pharmacological inhibition of sphingolipid synthesis on beta-cell function and diabetes progression has been confirmed not only in the ZDF rat but also in other rodent models [122-124]. However, since ceramide is also implicated in the mechanisms of insulin resistance [123], it is difficult in these in vivo studies to distinguish between the effects of the treatment on insulin sensitivity and those on beta-cell function.

Non-genetic models of glucolipotoxicity have been developed and most often use prolonged infusions of Intralipid, a soybean oil emulsion which generates a mixture of mostly unsaturated fatty acids [125] when co-injected with heparin. In these models, the effects of Intralipid or fatty-acid infusion on beta-cell function have been inconsistent, leading to either unaffected [77], enhanced $[126,127]$ or reduced $[9,61,128,129]$ insulin secretion. These discrepancies are likely due to differences in strain, sex, age, or infusion rates. For instance, Mason et al. [61] and Goh et al. [128] suggested that female Wistar rats are more susceptible to the deleterious effects of prolonged high fatty acid levels, and Steil et al. [127] have observed that a 96-h Intralipid infusion did not affect insulin secretion in male Sprague-Dawley rats. The influence of genetic predisposition on the insulin secretory response to excessive fatty acid levels is also illustrated by the observation that insulin secretion is impaired to a greater extent in heterozygous lean ZDF rats than in Wistar rats after Intralipid infusion [128]. Recent studies in our laboratory also highlight the importance of the age of the animals in the response to chronic fuel overload. In a first study we infused 8 week-old male Wistar rats alternatively with glucose for $4 \mathrm{~h}$ and Intralipid + heparin for $4 \mathrm{~h}$, for a total of $72 \mathrm{~h}$ [77]. Hyperglycemic clamps performed at the end of the infusion failed to detect any effects of the glucose + Intralipid infusion regimen on insulin secretion in vivo, as compared to control, saline-infused animals. Similarly, insulin secretion in response to glucose in isolated islets was unaffected. 
In animals infused with glucose only, we observed an increase in insulin mRNA levels, PDX-1 nuclear localization, and PDX-1 binding to the endogenous insulin gene promoter in islets. In contrast, in islets from animals infused with glucose + Intralipid, insulin mRNA levels were reduced, PDX-1 localization was shifted towards the cytosol, and occupancy of the endogenous insulin promoter by PDX-1 was markedly diminished [77]. These results demonstrate that fatty acid inhibition of the insulin gene also occurs in vivo, and represents an early defect that can be detected prior to any alteration in insulin secretion. The lack of effect of the infusion on insulin secretion in 8-week old rats prompted us to assess whether older animals would be more susceptible to nutrient overload. To test this possibility, we recently conducted a second study in which glucose and Intralipid were infused simultaneously and continuously for $72 \mathrm{~h}$ to either 8-week old or 6-month old Wistar rats (unpublished results). As in our first study, this infusion regimen did not alter insulin secretion in 8-week old rats, as assessed by hyperglycemic clamps at the end of the infusion. In marked contrast, infusion of glucose + Intralipid in 6-month old rats resulted in marked insulin resistance which was not adequately compensated for by a sufficient increase in insulin secretion in vivo, and in defective insulin secretion in vitro in isolated islets. The results from these two studies yield two important conclusions. First, defective insulin gene expression under glucolipotoxic conditions occurs in vivo and precedes abnormalities in insulin secretion. This confirms the physiological relevance of our previous in vitro findings $[17,18]$ and suggests that impaired insulin gene transcription might represent an early defect in nutrient-induced beta-cell failure. Second, young rats are resistant to the effects of nutrient oversupply, and such studies are probably better conducted in older animals, which more closely resemble the typical setting of type 2 diabetes in humans. Whether or not this age-dependent susceptibility to nutrient oversupply is related to the reduced beta-cell proliferative capacity in older rodents $[130,131]$ is unknown and currently under investigation.

\section{B. Studies in humans}

As in experimental animals, studies examining the effects of prolonged fatty acids on insulin secretion in humans have led to conflicting results. Initial reports from Boden and colleagues indicated that a 48-h lipid infusion induces an appropriate insulin secretory response in healthy subjects [132] but is defective in type 2 diabetic patients [133]. In contrast, Carpentier et al. [134] showed in non-diabetic individuals that an acute (90-min) lipid infusion elicits an increase in insulin secretion which disappears when the infusion is prolonged for $48 \mathrm{~h}$. The loss of insulin secretion is specific to the response to glucose, as the response to arginine remains normal [135]. The same group further showed that obese, but not diabetic, subjects are susceptible to the inhibitory effect of lipids on glucose-induced insulin secretion [136]. Importantly, the increase in insulin secretion observed in non-diabetic subjects in response to a 24-h glucose infusion does not occur if lipids are infused simultaneously with glucose [137]. Xiao et al [138] confirmed that fatty acids also alter beta-cell function in obese individuals when ingested orally, and observed interesting differences between saturated and polyunsaturated fatty acids. While polyunsaturated fatty acids impair insulin secretion directly, saturated fatty acids induce insulin resistance which was not adequately compensated for by an increase in beta-cell function [138]. The same group further observed that concomitant administration of the antioxidant taurine improved insulin resistance and beta-cell dysfunction induced by Intralipid infusion in vivo in humans, suggesting the possible contribution of oxidative stress [139].

Finally, the group of Cusi and De Fronzo has carried out a series of studies in non-diabetic subjects with and without family history of type 2 diabetes which clearly highlights the importance of genetic predisposition on the effects of chronically elevated fatty acids in humans. They showed that a 4-day Intralipid infusion enhances insulin secretion (taking into account insulin sensitivity) in control subjects but inhibits glucose-induced insulin secretion in individuals with a family history of type 2 diabetes [140]. This suggests that the genetic 
predisposition to developing type 2 diabetes might be dependent, at least in part, on the ability of the beta cell to increase insulin secretion in response to elevated fatty acid levels.

Importantly, treatment of susceptible subjects with Acipimox to decrease circulating fatty acid levels ameliorates insulin secretion [141].

\section{Conclusions}

In recent years, major progress has been made towards a better understanding of the cellular and molecular mechanisms of glucolipotoxicity in the beta-cell. The biochemical basis for the permissive effect of elevated glucose on the deleterious actions of fatty acids is better delineated; the mechanisms by which the combination of excessive levels of fatty acids and glucose alter beta cell function are beginning to be unraveled; and it is becoming clear that the various functional effects of fatty acids (i.e. decreased insulin secretion, impaired insulin gene expression, and beta-cell death by apoptosis) have different underlying mechanisms. Despite significant progress, however, a number of important questions remain. While it is now clear that triglyceride accumulation is more a symptom than a cause of glucolipotoxicity, the nature of the lipid-derived intermediates directly responsible for the detrimental effects of fatty acids is still elusive. In that regard, a role for cholesterol accumulation is also likely. Amongst the several candidates recently proposed to explain fatty-acid inhibition of insulin secretion, the role of UCP2 has become unclear, while convincing evidence seems to implicate the novel isoform PKC $\varepsilon$ as well as late exocytotic events. Regarding fatty-acid impairment of the insulin gene, a complex picture has emerged which includes prolonged activation of ERK1/2 via de novo ceramide synthesis, downregulation of PASK, and altered binding activities of the transcription factors PDX-1, MafA, and C/EBP $\beta$. The role of the UPR under conditions of mild glucolipotoxicity (i.e., not associated with cell death) appears limited, although our current hypothesis is that early activation of ATF6 represses insulin gene transcription and thereby contributes to the reduction in proinsulin biosynthesis in an attempt to decrease the load to the ER. As conditions deteriorate, unresolved and sustained unfolded protein response likely leads to ER stress and, consequently, to beta-cell apoptosis under severe glucolipotoxic conditions. The necessity to confirm in vitro findings under physiological conditions has prompted several groups, including ours, to address these questions in in vivo models. Our studies have confirmed that the decrease in insulin gene expression is an early defect which precedes any detectable abnormality in insulin secretion, and have established that prolonged infusions of glucose and Intralipid impairs beta-cell function in old, but not young, animals, raising caution on the use of younger rodents to examine mechanisms of beta-cell failure. While still debated, the role of glucolipotoxicity in humans has been clearly demonstrated in several studies, at least in individuals genetically predisposed to developing type 2 diabetes.

We propose that the uncertainties regarding the role of glucolipotoxicity and its manifestations stem from the fact that it is being considered, as its name implies, as a deleterious phenomenon, while in fact the beta-cell's response to nutrient excess likely represents a continuum encompassing all stages of beta-cell compensation and beta-cell failure. In that sense, some of the early manifestations of glucolipotoxicity should actually be considered as a positive response and would be more appropriately named «glucolipoadaptation », as proposed by Prentki and Nolan [2]. Examples of such adaptive responses are the early decrease in insulin gene expression, as an attempt to protect the ER from overload [77], or the increase in UCP2 expression, as a defense mechanism against oxidative stress [68].

The hypothesis that glucolipotoxicity represents a continuum from an adaptative response to a deleterious outcome is illustrated in Figure 4. According to this view, in normoglycemic individuals experiencing weight gain, the beta cell mounts a compensatory response to counter insulin resistance associated with obesity. This response involves coordinated increases in betacell mass, insulin biosynthesis, and insulin secretion, and likely relies on an enhanced 
responsiveness to fatty acids $[142,143]$. The magnitude of the compensatory beta-cell response is probably genetically determined and, in turn, is a major determinant of the long-term ability of an individual to maintain glucose homeostasis in the face of insulin resistance. In contrast, in genetically predisposed individuals beta-cell compensation eventually becomes insufficient and the beta cell is no longer able to sustain a secretory response that matches the demand imposed by insulin resistance. It is probably during this decompensation phase that glucolipotoxicity plays a major role, in that hyperglycemia is the permissive factor by which elevated fatty acids affect beta-cell function. Our data suggest that one of the first functional defect at this stage is a decrease in insulin gene expression, which likely contributes to eventual beta-cell failure since maintenance of adequate intracellular stores of insulin is necessary to sustain increased secretory demand [144]. Beta-cell decompensation evolves towards beta-cell failure when fasting hyperglycemia occurs. At this stage, it is likely that both glucotoxicity and glucolipotoxicity contribute to the decline in insulin secretion observed over time during the years following diagnosis of type 2 diabetes [3]. This model is based on extensive experimental evidence obtained in vitro and in rodents, but additional investigation is necessary to ascertain the precise contribution of glucolipotoxicity to the pathogenesis of type 2 diabetes in humans.

\section{Acknowledgments}

Work performed in our laboratory was supported by the US National Institutes of Health (R01-DK58096 from NIDDK) and the Canadian Institutes of Health Research (MOP 77686). V.P. holds the Canada Research Chair in Diabetes and Pancreatic Beta-cell Function. G.F. is supported by a postdoctoral fellowship from the Canadian Diabetes Association. B.Z. is supported by the Montreal Diabetes Research Center/Merck Frosst post-doctoral fellowship.

\section{References}

1. DeFronzo RA. From the Triumvirate to the Ominous Octet: A New Paradigm for the Treatment of Type 2 Diabetes Mellitus. Diabetes 2009;58:773-795. [PubMed: 19336687]

2. Prentki M, Nolan CJ. Islet beta cell failure in type 2 diabetes. J Clin Invest 2006;116:1802-1812. [PubMed: 16823478]

3. U.K. prospective diabetes study 16 . Overview of 6 years' therapy of type II diabetes: a progressive disease. U.K. Prospective Diabetes Study Group. Diabetes 1995;44:1249-1258. [PubMed: 7589820]

4. Kahn SE, Haffner SM, Heise MA, Herman WH, Holman RR, Jones NP, Kravitz BG, Lachin JM, O'Neill MC, Zinman B, Viberti G. the ADOPT Study Group, Glycemic Durability of Rosiglitazone, Metformin, or Glyburide Monotherapy. N Engl J Med 2006;355:2427-2443. [PubMed: 17145742]

5. Robertson, RP.; Harmon, JS.; Tanaka, Y.; Sacchi, G.; Tran, POT.; Gleason, CE.; Poitout, V. Glucose toxicity of the beta-cell: cellular and molecular mechanisms Diabetes Mellitus. In: Le Roith, D.; Taylor, SI.; Olefsky, JM., editors. A fundamental and clinical text. 2. Lippincott Williams \& Wilkins; Philadelphia: 2000. p. 125-132.

6. Unger RH. Lipotoxicity in the pathogenesis of obesity-dependent NIDDM. Genetic and clinical implications. Diabetes 1995;44:863-870. [PubMed: 7621989]

7. Prentki M, Corkey BE. Are the $\beta$-cell signaling molecules malonyl-CoA and cytosolic long-chain acylCoA implicated in multiple tissue defects of obesity and NIDDM? Diabetes 1996;45:273-283. [PubMed: 8593930]

8. Poitout V, Robertson RP. Minireview: Secondary beta-cell failure in type 2 diabetes--a convergence of glucotoxicity and lipotoxicity. Endocrinology 2002;143:339-342. [PubMed: 11796484]

9. Sako Y, Grill VE. A 48-hour lipid infusion in the rat time-dependently inhibits glucose-induced insulin secretion and $\beta$-cell oxidation through a process likely coupled to fatty acid oxidation. Endocrinology 1990;127:1580-1589. [PubMed: 1698143]

10. Elks ML. Chronic perifusion of rat islets with palmitate suppresses glucose-stimulated insulin release. Endocrinology 1993;133:208-214. [PubMed: 8319569]

11. Zhou YP, Grill V. Long term exposure to fatty acids and ketones inhibits B-cell functions in human pancreatic islets of Langerhans. J Clin Endocrinol Metab 1995;80:1584-1590. [PubMed: 7745004] 
12. Zhou YP, Grill VE. Long-term exposure of rat pancreatic islets to fatty acids inhibits glucose-induced insulin secretion and biosynthesis through a glucose-fatty acid cycle. J Clin Invest 1994;93:870-876. [PubMed: 8113418]

13. Gremlich S, Bonny C, Waeber G, Thorens B. Fatty acids decrease IDX-1 expression in rat pancreatic islets and reduce GLUT2, glucokinase, insulin, and somatostatin levels. J Biol Chem 1997;272:30261-30269. [PubMed: 9374511]

14. Ritz-Laser B, Meda P, Constant I, Klages N, Charollais A, Morales A, Magnan C, Ktorza A, Philippe J. Glucose-induced preproinsulin gene expression is inhibited by the free-fatty acid palmitate. Endocrinology 1999;140:4005-4014. [PubMed: 10465270]

15. Jacqueminet S, Briaud I, Rouault C, Reach G, Poitout V. Inhibition of insulin gene expression by long-term exposure of pancreatic beta-cells to palmitate is dependent upon the presence of a stimulatory glucose concentration. Metabolism 2000;49:532-536. [PubMed: 10778881]

16. Briaud I, Harmon JS, Kelpe CL, Segu VB, Poitout V. Lipotoxicity of the pancreatic beta-cell is associated with glucose-dependent esterification of fatty acids into neutral lipids. Diabetes 2001;50:315-321. [PubMed: 11272142]

17. Kelpe CL, Moore PC, Parazzoli SD, Wicksteed B, Rhodes CJ, Poitout V. Palmitate inhibition of insulin gene expression is mediated at the transcriptional level via ceramide synthesis. J Biol Chem 2003;278:30015-30021. [PubMed: 12771145]

18. Hagman DK, Hays LB, Parazzoli SD, Poitout V. Palmitate inhibits insulin gene expression by altering PDX-1 nuclear localization and reducing MafA expression in isolated rat islets of Langerhans. J Biol Chem 2005;280:32413-32418. [PubMed: 15944145]

19. Pick A, Clark J, Kubstrup C, Levisetti M, Pugh W, Bonner-Weir S, Polonsky K. Role of apoptosis in failure of beta-cell mass compensation for insulin resistance and beta-cell defects in the male Zucker Diabetes Fatty rat. Diabetes 1998;47:358-364. [PubMed: 9519740]

20. Shimabukuro M, Zhou YT, Levi M, Unger RH. Fatty-acid-induced beta-cell apoptosis: a link between obesity and diabetes. Proc Natl Acad Sci USA 1998;95:2498-2502. [PubMed: 9482914]

21. Cnop M, Hannaert JC, Hoorens A, Eizirik DL, Pipeleers DG. Inverse relationship between cytotoxicity of free fatty acids in pancreatic islet cells and cellular triglyceride accumulation. Diabetes 2001;50:1771-1777. [PubMed: 11473037]

22. Maedler K, Spinas GA, Dyntar D, Moritz W, Kaiser N, Donath MY. Distinct effects of saturated and monounsaturated fatty acids on beta-cell turnover and function. Diabetes 2001;50:69-76. [PubMed: 11147797]

23. Lupi R, Dotta F, Marselli L, Del Guerra S, Masini M, Santangelo C, Patane G, Boggi U, Piro S, Anello M, Bergamini E, Mosca F, Di Mario U, Del Prato S, Marchetti P. Prolonged exposure to free fatty acids has cytostatic and pro-apoptotic effects on human pancreatic islets: evidence that betacell death is caspase mediated, partially dependent on ceramide pathway, and Bcl-2 regulated. Diabetes 2002;51:1437-1442. [PubMed: 11978640]

24. Wrede CE, Dickson LM, Lingohr MK, Briaud I, Rhodes CJ. Protein kinase B/Akt prevents fatty acidinduced apoptosis in pancreatic beta-cells (INS-1). J Biol Chem 2002;277:49676-49684. [PubMed: 12393870]

25. Piro S, Anello M, Di Pietro C, Lizzio MN, Patane G, Rabuazzo AM, Vigneri R, Purrello M, Purrello F. Chronic exposure to free fatty acids or high glucose induces apoptosis in rat pancreatic islets: Possible role of oxidative stress. Metabolism 2002;51:1340-1347. [PubMed: 12370856]

26. Maedler K, Oberholzer J, Bucher P, Spinas GA, Donath MY. Monounsaturated fatty acids prevent the deleterious effects of palmitate and high glucose on human pancreatic beta-cell turnover and function. Diabetes 2003;52:726-733. [PubMed: 12606514]

27. Maestre I, Jordan J, Calvo S, Reig JA, Cena V, Soria B, Prentki M, Roche E. Mitochondrial dysfunction is involved in apoptosis induced by serum withdrawal and fatty acids in the beta-cell line INS-1. Endocrinology 2003;144:335-345. [PubMed: 12488362]

28. El-Assaad W, Buteau J, Peyot ML, Nolan C, Roduit R, Hardy S, Joly E, Dbaibo G, Rosenberg L, Prentki M. Saturated fatty acids synergize with elevated glucose to cause pancreatic beta-cell death. Endocrinology 2003;144:4154-4163. [PubMed: 12933690] 
29. Harmon JS, Gleason CE, Tanaka Y, Poitout V, Robertson RP. Antecedent hyperglycemia, not hyperllipidemia, is associated with increased islet triacylglycerol content and decreased insulin gene mRNA level in Zucker Diabetic Fatty rats. Diabetes 2001;50:2481-2486. [PubMed: 11679425]

30. Briaud I, Kelpe CL, Johnson LM, Tran POT, Poitout V. Differential effects of hyperlipidemia on insulin secretion in islets of Langerhans from hyperglycemic vs. normoglycemic rats. Diabetes 2002;51:662-668. [PubMed: 11872664]

31. Prentki M, Joly E, El-Assaad W, Roduit R. Malonyl-CoA signaling, lipid partitioning, and glucolipotoxicity: role in beta-cell adaptation and failure in the etiology of diabetes. Diabetes 2002;51 (Suppl 3):S405-413. [PubMed: 12475783]

32. Poitout V. Lipid partitioning in the pancreatic beta-cell: physiologic and pathophysiologic implications. Curr Opin Endocrinol Diabetes 2002;9:152-159.

33. Brun T, Roche E, Assimacopoulos-Jeannet F, Corkey BE, Kim KH, Prentki M. Evidence fore anaplerotic/malonyl-CoA pathway in pancreatic beta-cell nutrient signaling. Diabetes 1996;45:190198. [PubMed: 8549864]

34. Roche E, Farfari S, Witters LA, Assimacopoulos-Jeannet F, Thumelin S, Brun T, Corkey BE, Saha AK, Prentki M. Long-term exposure of beta-INS cells to high glucose concentrations increases anaplerosis, lipogenesis, and lipogenic gene expression. Diabetes 1998;47:1086-1094. [PubMed: 9648832]

35. Ruderman N, Prentki M. AMP kinase and malonyl-CoA: Targets for therapy of the metabolic syndrome. Nat Rev Drug Discov 2004;3:340-351. [PubMed: 15060529]

36. Hardie DG. Minireview: the AMP-activated protein kinase cascade: the key sensor of cellular energy status. Endocrinology 2003;144:5179-5183. [PubMed: 12960015]

37. Salt IP, Johnson G, Ashcroft SJ, Hardie DG. AMP-activated protein kinase is activated by low glucose in cell lines derived from pancreatic beta-cells, and may regulate insulin release. Biochem $\mathrm{J}$ 1998;335:533-539. [PubMed: 9794792]

38. Wang X, Zhou L, Li G, Luo T, Gu Y, Qian L, Fu X, Li F, Li J, Luo M. Palmitate activates AMPactivated protein kinase and regulates insulin secretion from beta cells. Biochem Biophys Res Commun 2007;352:463-468. [PubMed: 17118340]

39. Foufelle F, Ferre P. New perspectives in the regulation of hepatic glycolytic and lipogenic genes by insulin and glucose: a role for the transcription factor sterol regulatory element binding protein-1c. Biochem J 2002;366:377-391. [PubMed: 12061893]

40. Choe SS, Choi AH, Lee JW, Kim KH, Chung JJ, Park J, Lee KM, Park KG, Lee IK, Kim JB. Chronic activation of liver $\mathrm{X}$ receptor induces beta-cell apoptosis through hyperactivation of lipogenesis: liver $\mathrm{X}$ receptor-mediated lipotoxicity in pancreatic beta-cells. Diabetes 2007;56:1534-1543. [PubMed: 17369526]

41. Listenberger LL, Han X, Lewis SE, Cases S, Farese RV Jr, Ory DS, Schaffer JE. Triglyceride accumulation protects against fatty acid-induced lipotoxicity. Proc Natl Acad Sci U S A 2003;100:3077-3082. [PubMed: 12629214]

42. Busch AK, Gurisik E, Cordery DV, Sudlow M, Denyer GS, Laybutt DR, Hughes WE, Biden TJ. Increased fatty acid desaturation and enhanced expression of stearoyl coenzyme A desaturase protects pancreatic beta-cells from lipoapoptosis. Diabetes 2005;54:2917-2924. [PubMed: 16186393]

43. Ntambi JM, Miyazaki M, Stoehr JP, Lan H, Kendziorski CM, Yandell BS, Song Y, Cohen P, Friedman JM, Attie AD. Loss of stearoyl-CoA desaturase-1 function protects mice against adiposity. Proc Natl Acad Sci U S A 2002;99:11482-11486. [PubMed: 12177411]

44. Flowers JB, Rabaglia ME, Schueler KL, Flowers MT, Lan H, Keller MP, Ntambi JM, Attie AD. Loss of stearoyl-CoA desaturase-1 improves insulin sensitivity in lean mice but worsens diabetes in leptindeficient obese mice. Diabetes 2007;56:1228-1239. [PubMed: 17369521]

45. Nolan CJ, Prentki M. The islet beta-cell: fuel responsive and vulnerable. Trends Endocrinol Metab 2008;19:285-291. [PubMed: 18774732]

46. Prentki M, Madiraju SR. Glycerolipid metabolism and signaling in health and disease. Endocr Rev 2008;29:647-676. [PubMed: 18606873]

47. Shimabukuro M, Higa M, Zhou YT, Wang MY, Newgard CB, Unger RH. Lipoapoptosis in beta-cells of obese prediabetic fa/fa rats. Role of serine palmitoyltransferase overexpression. J Biol Chem 1998;273:32487-32490. [PubMed: 9829981] 
48. Moore PC, Ugas MA, Hagman DK, Parazzoli SD, Poitout V. Evidence against the involvement of oxidative stress in Fatty Acid inhibition of insulin secretion. Diabetes 2004;53:2610-2616. [PubMed: 15448091]

49. Cnop M, Hannaert JC, Grupping AY, Pipeleers DG. Low density lipoprotein can cause death of islet beta-cells by its cellular uptake and oxidative modification. Endocrinology 2002;143:3449-3453. [PubMed: 12193557]

50. Abderrahmani A, Niederhauser G, Favre D, Abdelli S, Ferdaoussi M, Yang JY, Regazzi R, Widmann C, Waeber G. Human high-density lipoprotein particles prevent activation of the JNK pathway induced by human oxidised low-density lipoprotein particles in pancreatic beta cells. Diabetologia 2007;50:1304-1314. [PubMed: 17437081]

51. Brunham LR, Kruit JK, Pape TD, Timmins JM, Reuwer AQ, Vasanji Z, Marsh BJ, Rodrigues B, Johnson JD, Parks JS, Verchere CB, Hayden MR. Beta-cell ABCA1 influences insulin secretion, glucose homeostasis and response to thiazolidinedione treatment. Nat Med 2007;13:340-347. [PubMed: 17322896]

52. Ishikawa M, Iwasaki Y, Yatoh S, Kato T, Kumadaki S, Inoue N, Yamamoto T, Matsuzaka T, Nakagawa Y, Yahagi N, Kobayashi K, Takahashi A, Yamada N, Shimano H. Cholesterol accumulation and diabetes in pancreatic beta-cell-specific SREBP-2 transgenic mice: a new model for lipotoxicity. J Lipid Res 2008;49:2524-2534. [PubMed: 18682608]

53. Mitro N, Mak PA, Vargas L, Godio C, Hampton E, Molteni V, Kreusch A, Saez E. The nuclear receptor LXR is a glucose sensor. Nature 2007;445:219-223. [PubMed: 17187055]

54. Briscoe CP, Tadayyon M, Andrews JL, Benson WG, Chambers JK, Eilert MM, Ellis C, Elshourbagy NA, Goetz AS, Minnick DT, Murdock PR, Sauls HR Jr, Shabon U, Spinage LD, Strum JC, Szekeres PG, Tan KB, Way JM, Ignar DM, Wilson S, Muir AI. The orphan G protein-coupled receptor GPR40 is activated by medium and long chain fatty acids. J Biol Chem 2003;278:11303-11311. [PubMed: 12496284]

55. Itoh Y, Kawamata Y, Harada M, Kobayashi M, Fujii R, Fukusumi S, Ogi K, Hosoya M, Tanaka Y, Uejima H, Tanaka H, Maruyama M, Satoh R, Okubo S, Kizawa H, Komatsu H, Matsumura F, Noguchi Y, Shinohara T, Hinuma S, Fujisawa Y, Fujino M. Free fatty acids regulate insulin secretion from pancreatic beta cells through GPR40. Nature 2003;422:173-176. [PubMed: 12629551]

56. Steneberg P, Rubins N, Bartoov-Shifman R, Walker MD, Edlund H. The FFA receptor GPR40 links hyperinsulinemia, hepatic steatosis, and impaired glucose homeostasis in mouse. Cell Metabolism 2005;1:245-258. [PubMed: 16054069]

57. Latour MG, Alquier T, Oseid E, Tremblay C, Jetton TL, Luo J, Lin DC, Poitout V. GPR40 is necessary but not sufficient for fatty acid stimulation of insulin secretion in vivo. Diabetes 2007;56:1087-1094. [PubMed: 17395749]

58. Kebede M, Alquier T, Latour MG, Semache M, Tremblay C, Poitout V. The fatty acid receptor GPR40 plays a role in insulin secretion in vivo after high-fat feeding. Diabetes 2008;57:2432-2437. [PubMed: 18559658]

59. Cnop M, Igoillo-Esteve M, Cunha DA, Ladriere L, Eizirik DL. An update on lipotoxic endoplasmic reticulum stress in pancreatic beta-cells. Biochem Soc Trans 2008;36:909-915. [PubMed: 18793160]

60. Tan CP, Feng Y, Zhou YP, Eiermann GJ, Petrov A, Zhou C, Lin S, Salituro G, Meinke P, Mosley R, Akiyama TE, Einstein M, Kumar S, Berger JP, Mills SG, Thornberry NA, Yang L, Howard AD. Selective small-molecule agonists of $\mathrm{G}$ protein-coupled receptor 40 promote glucose-dependent insulin secretion and reduce blood glucose in mice. Diabetes 2008;57:2211-2219. [PubMed: 18477808]

61. Mason TM, Goh T, Tchipashvili V, Sandhu H, Gupta N, Lewis GF, Giacca A. Prolonged elevation of plasma free fatty acids desensitizes the insulin secretory response to glucose in vivo in rats. Diabetes 1999;48:524-530. [PubMed: 10078552]

62. Paolisso G, Gambardella A, Amato L, Tortoriello R, D’Amore A, Varrichio M, D’Onofrio F. Opposite effects of short- and long-term fatty acid infusion on insulin secretion in healthy subjects. Diabetologia 1995;38:1295-1299. [PubMed: 8582538]

63. Zhang CY, Baffy G, Perret P, Krauss S, Peroni O, Grujic D, Hagen T, Vidal-Puig AJ, Boss O, Kim YB, Zheng XX, Wheeler MB, Shulman GI, Chan CB, Lowell BB. Uncoupling protein-2 negatively regulates insulin secretion and is a major link between obesity, beta-cell dysfunction, and Type 2 diabetes. Cell 2001;105:745-755. [PubMed: 11440717] 
64. Nedergaard J, Ricquier D, Kozak LP. Uncoupling proteins: current status and therapeutic prospects. EMBO Rep 2005;6:917-921. [PubMed: 16179945]

65. Chan CB, MacDonald PE, Saleh MC, Johns DC, Marban E, Wheeler MB. Overexpression of uncoupling protein 2 inhibits glucose-stimulated insulin secretion from rat islets. Diabetes 1999;48:1482-1486. [PubMed: 10389858]

66. Chan CB, De Leo D, Joseph JW, McQuaid TS, Ha XF, Xu F, Tsushima RG, Pennefather PS, Salapatek AM, Wheeler MB. Increased uncoupling protein-2 levels in beta-cells are associated with impaired glucose-stimulated insulin secretion: mechanism of action. Diabetes 2001;50:1302-1310. [PubMed: 11375330]

67. Joseph JW, Koshkin V, Zhang CY, Wang J, Lowell BB, Chan CB, Wheeler MB. Uncoupling protein 2 knockout mice have enhanced insulin secretory capacity after a high-fat diet. Diabetes 2002;51:3211-3219. [PubMed: 12401712]

68. Pi J, Bai Y, Daniel KW, Liu D, Lyght O, Edelstein D, Brownlee M, Corkey BE, Collins S. Persistent Oxidative Stress Due to Absence of Uncoupling Protein 2 Associated with Impaired Pancreatic BetaCell Function. Endocrinology. 2009

69. Lameloise N, Muzzin P, Prentki M, Assimacopoulos-Jeannet F. Uncoupling protein 2: a possible link between fatty acid excess and impaired glucose-induced insulin secretion? Diabetes 2001;50:803809. [PubMed: 11289045]

70. Patane G, Anello M, Piro S, Vigneri R, Purrello F, Rabuazzo AM. Role of ATP production and uncoupling protein-2 in the insulin secretory defect induced by chronic exposure to high glucose or free fatty acids and effects of peroxisome proliferator-activated receptor-gamma inhibition. Diabetes 2002;51:2749-2756. [PubMed: 12196468]

71. Produit-Zengaffinen N, Davis-Lameloise N, Perreten H, Becard D, Gjinovci A, Keller PA, Wollheim CB, Herrera P, Muzzin P, Assimacopoulos-Jeannet F. Increasing uncoupling protein-2 in pancreatic beta cells does not alter glucose-induced insulin secretion but decreases production of reactive oxygen species. Diabetologia 2007;50:84-93. [PubMed: 17131143]

72. Schmitz-Peiffer C, Laybutt DR, Burchfield JG, Gurisik E, Narasimhan S, Mitchell CJ, Pedersen DJ, Braun U, Cooney GJ, Leitges M, Biden TJ. Inhibition of PKCepsilon improves glucose-stimulated insulin secretion and reduces insulin clearance. Cell Metab 2007;6:320-328. [PubMed: 17908560]

73. Cantley J, Burchfield JG, Pearson GL, Schmitz-Peiffer C, Leitges M, Biden TJ. Deletion of PKC \{varepsilon\} selectively enhances the amplifying pathways of glucose-stimulated insulin secretion via increased lipolysis in mouse \{beta\}-cells. Diabetes. 2009

74. Peyot ML, Guay C, Latour MG, Lamontagne J, Lussier R, Pineda M, Ruderman NB, Haemmerle G, Zechner R, Joly E, Madiraju SR, Poitout V, Prentki M. Adipose Triglyceride Lipase Is Implicated in Fuel- and Non-fuel-stimulated Insulin Secretion. J Biol Chem 2009;284:16848-16859. [PubMed: 19389712]

75. Kato T, Shimano H, Yamamoto T, Yokoo T, Endo Y, Ishikawa M, Matsuzaka T, Nakagawa Y, Kumadaki S, Yahagi N, Takahashi A, Sone H, Suzuki H, Toyoshima H, Hasty AH, Takahashi S, Gomi H, Izumi T, Yamada N. Granuphilin is activated by SREBP-1c and involved in impaired insulin secretion in diabetic mice. Cell Metab 2006;4:143-154. [PubMed: 16890542]

76. Olofsson CS, Collins S, Bengtsson M, Eliasson L, Salehi A, Shimomura K, Tarasov A, Holm C, Ashcroft F, Rorsman P. Long-term exposure to glucose and lipids inhibits glucose-induced insulin secretion downstream of granule fusion with plasma membrane. Diabetes 2007;56:1888-1897. [PubMed: 17456851]

77. Hagman DK, Latour MG, Chakrabarti SK, Fontes G, Amyot J, Tremblay C, Semache M, Lausier JA, Roskens V, Mirmira RG, Jetton TL, Poitout V. Cyclical and alternating infusions of glucose and intralipid in rats inhibit insulin gene expression and Pdx-1 binding in islets. Diabetes 2008;57:424431. [PubMed: 17991758]

78. Harmon JS, Stein R, Robertson RP. Oxidative stress-mediated, post-translational loss of MafA protein as a contributing mechanism to loss of insulin gene expression in glucotoxic beta cells. J Biol Chem 2005;280:11107-11113. [PubMed: 15664999]

79. Mathias S, Pena LA, Kolesnick RN. Signal transduction of stress via ceramide. Biochem J 1998;335 (Pt 3):465-480. [PubMed: 9794783] 
80. Henderson E, Stein R. c-jun inhibits transcriptional activation by the insulin enhancer, and the insulin control element is the target of control. Mol Cell Biol 1994;14:655-662. [PubMed: 8264634]

81. Robinson GL, Henderson E, Massari ME, Murre C, Stein R. c-jun inhibits insulin control elementmediated transcription by affecting the transactivation potential of the E2A gene products. Mol Cell Biol 1995;15:1398-1404. [PubMed: 7862133]

82. Kaneto H, Xu G, Fujii N, Kim S, Bonner-Weir S, Weir GC. Involvement of c-Jun N-terminal Kinase in Oxidative Stress-mediated Suppression of Insulin Gene Expression. J Biol Chem 2002;277:30010 30018. [PubMed: 12011047]

83. Solinas G, Naugler W, Galimi F, Lee MS, Karin M. Saturated fatty acids inhibit induction of insulin gene transcription by JNK-mediated phosphorylation of insulin-receptor substrates. Proc Natl Acad Sci U S A 2006;103:16454-16459. [PubMed: 17050683]

84. Fontes G, Semache M, Hagman DK, Tremblay C, Shah R, Rhodes CJ, Rutter J, Poitout V. Involvement of PAS Kinase and ERK1/2 in Palmitate Inhibition of Insulin Gene Expression In Pancreatic Beta-Cells. Diabetes. 2009 published ahead of print June 5, 2009. 10.2337/db08-0579

85. Amezcua CA, Harper SM, Rutter J, Gardner KH. Structure and interactions of PAS kinase N-terminal PAS domain: model for intramolecular kinase regulation. Structure 2002;10:1349-1361. [PubMed: 12377121]

86. Rutter J, Probst BL, McKnight SL. Coordinate regulation of sugar flux and translation by PAS kinase. Cell 2002;111:17-28. [PubMed: 12372297]

87. Wilson WA, Skurat AV, Probst B, de Paoli-Roach A, Roach PJ, Rutter J. Control of mammalian glycogen synthase by PAS kinase. Proc Natl Acad Sci U S A 2005;102:16596-16601. [PubMed: 16275910]

88. da Silva Xavier G, Rutter J, Rutter GA. Involvement of Per-Arnt-Sim (PAS) kinase in the stimulation of preproinsulin and pancreatic duodenum homeobox 1 gene expression by glucose. Proc Natl Acad Sci U S A 2004;101:8319-8324. [PubMed: 15148392]

89. Lu M, Seufert J, Habener JF. Pancreatic $\beta$-cell-specific repression of insulin gene transcription by CCAAT/Enhancer-binding protein $\beta$. Inhibitory interactions with basic helix-loop-helix transcription factor E47. J Biol Chem 1997;272:28349-28359. [PubMed: 9353292]

90. Plaisance V, Perret V, Favre D, Abderrahmani A, Yang JY, Widmann C, Regazzi R. Role of the transcriptional factor C/EBPbeta in free fatty acid-elicited beta-cell failure. Mol Cell Endocrinol 2009;305:47-55. [PubMed: 19133313]

91. Lawrence MC, McGlynn K, Park BH, Cobb MH. ERK1/2-dependent activation of transcription factors required for acute and chronic effects of glucose on the insulin gene promoter. J Biol Chem 2005;280:26751-26759. [PubMed: 15899886]

92. Eizirik DL, Cardozo AK, Cnop M. The role for endoplasmic reticulum stress in diabetes mellitus. Endocr Rev 2008;29:42-61. [PubMed: 18048764]

93. Laybutt DR, Preston AM, Akerfeldt MC, Kench JG, Busch AK, Biankin AV, Biden TJ. Endoplasmic reticulum stress contributes to beta cell apoptosis in type 2 diabetes. Diabetologia 2007;50:752-763. [PubMed: 17268797]

94. Karaskov E, Scott C, Zhang L, Teodoro T, Ravazzola M, Volchuk A. Chronic palmitate but not oleate exposure induces endoplasmic reticulum stress, which may contribute to INS-1 pancreatic beta-cell apoptosis. Endocrinology 2006;147:3398-3407. [PubMed: 16601139]

95. Cnop M, Ladriere L, Hekerman P, Ortis F, Cardozo AK, Dogusan Z, Flamez D, Boyce M, Yuan J, Eizirik DL. Selective inhibition of EIF2alpha dephosphorylation potentiates fatty acid-induced er stress and causes pancreatic beta -cell dysfunction and apoptosis. J Biol Chem. 2006

96. Wang H, Kouri G, Wollheim CB. ER stress and SREBP-1 activation are implicated in beta-cell glucolipotoxicity. J Cell Sci 2005;118:3905-3915. [PubMed: 16091421]

97. Kharroubi I, Ladriere L, Cardozo AK, Dogusan Z, Cnop M, Eizirik DL. Free fatty acids and cytokines induce pancreatic beta-cell apoptosis by different mechanisms: role of nuclear factor-kappaB and endoplasmic reticulum stress. Endocrinology 2004;145:5087-5096. [PubMed: 15297438]

98. Martinez SC, Tanabe K, Cras-Meneur C, Abumrad NA, Bernal-Mizrachi E, Permutt MA. Inhibition of Foxo1 protects pancreatic islet beta-cells against fatty acid and endoplasmic reticulum stressinduced apoptosis. Diabetes 2008;57:846-859. [PubMed: 18174526] 
99. Cunha DA, Hekerman P, Ladriere L, Bazarra-Castro A, Ortis F, Wakeham MC, Moore F, Rasschaert J, Cardozo AK, Bellomo E, Overbergh L, Mathieu C, Lupi R, Hai T, Herchuelz A, Marchetti P, Rutter GA, Eizirik DL, Cnop M. Initiation and execution of lipotoxic ER stress in pancreatic betacells. J Cell Sci 2008;121:2308-2318. [PubMed: 18559892]

100. Bachar E, Ariav Y, Ketzinel-Gilad M, Cerasi E, Kaiser N, Leibowitz G. Glucose amplifies fatty acid-induced endoplasmic reticulum stress in pancreatic beta-cells via activation of mTORC1. PLoS One 2009;4:e4954. [PubMed: 19305497]

101. Gwiazda KS, Yang TL, Lin Y, Johnson JD. Effects of palmitate on ER and cytosolic Ca2+ homeostasis in beta-cells. Am J Physiol Endocrinol Metab 2009;296:E690-701. [PubMed: 19141690]

102. Moore PC, Lin DC, Luo J, Poitout V. Deletion of the GPR40 gene impairs fatty-acid potentiation of insulin secretion in isolated mouse islets. Diabetes 2005;54(Suppl 1):A83.

103. Seo HY, Kim YD, Lee KM, Min AK, Kim MK, Kim HS, Won KC, Park JY, Lee KU, Choi HS, Park KG, Lee IK. Endoplasmic reticulum stress-induced activation of activating transcription factor 6 decreases insulin gene expression via up-regulation of orphan nuclear receptor small heterodimer partner. Endocrinology 2008;149:3832-3841. [PubMed: 18450959]

104. Evans-Molina C, Robbins RD, Kono T, Tersey SA, Vestermark GL, Nunemaker CS, Garmey JC, Deering TG, Keller SR, Maier B, Mirmira RG. Peroxisome proliferator-activated receptor gamma activation restores islet function in diabetic mice through reduction of endoplasmic reticulum stress and maintenance of euchromatin structure. Mol Cell Biol 2009;29:2053-2067. [PubMed: 19237535]

105. Pirot P, Naamane N, Libert F, Magnusson NE, Orntoft TF, Cardozo AK, Eizirik DL. Global profiling of genes modified by endoplasmic reticulum stress in pancreatic beta cells reveals the early degradation of insulin mRNAs. Diabetologia 2007;50:1006-1014. [PubMed: 17333111]

106. Wang X, Li H, De Leo D, Guo W, Koshkin V, Fantus IG, Giacca A, Chan CB, Der S, Wheeler MB. Gene and protein kinase expression profiling of reactive oxygen species-associated lipotoxicity in the pancreatic beta-cell line MIN6. Diabetes 2004;53:129-140. [PubMed: 14693707]

107. Morgan D, Oliveira-Emilio HR, Keane D, Hirata AE, Santos da Rocha M, Bordin S, Curi R, Newsholme P, Carpinelli AR. Glucose, palmitate and pro-inflammatory cytokines modulate production and activity of a phagocyte-like NADPH oxidase in rat pancreatic islets and a clonal beta cell line. Diabetologia 2007;50:359-369. [PubMed: 17151863]

108. Busch AK, Cordery D, Denyer GS, Biden TJ. Expression profiling of palmitate- and oleate-regulated genes provides novel insights into the effects of chronic lipid exposure on pancreatic beta-cell function. Diabetes 2002;51:977-987. [PubMed: 11916915]

109. Jeffrey KD, Alejandro EU, Luciani DS, Kalynyak TB, Hu X, Li H, Lin Y, Townsend RR, Polonsky KS, Johnson JD. Carboxypeptidase E mediates palmitate-induced beta-cell ER stress and apoptosis. Proc Natl Acad Sci U S A 2008;105:8452-8457. [PubMed: 18550819]

110. Lai E, Bikopoulos G, Wheeler MB, Rozakis-Adcock M, Volchuk A. Differential activation of ER stress and apoptosis in response to chronically elevated free fatty acids in pancreatic beta-cells. Am J Physiol Endocrinol Metab 2008;294:E540-550. [PubMed: 18198352]

111. Huang CJ, Lin CY, Haataja L, Gurlo T, Butler AE, Rizza RA, Butler PC. High expression rates of human islet amyloid polypeptide induce endoplasmic reticulum stress mediated beta-cell apoptosis, a characteristic of humans with type 2 but not type 1 diabetes. Diabetes 2007;56:2016-2027. [PubMed: 17475933]

112. Graier WF, Malli R, Kostner GM. Mitochondrial protein phosphorylation: instigator or target of lipotoxicity? Trends Endocrinol Metab 2009;20:186-193. [PubMed: 19356948]

113. Koshkin V, Dai FF, Robson-Doucette CA, Chan CB, Wheeler MB. Limited mitochondrial permeabilization is an early manifestation of palmitate-induced lipotoxicity in pancreatic beta-cells. J Biol Chem 2008;283:7936-7948. [PubMed: 18162472]

114. Luciani DS, Gwiazda KS, Yang TL, Kalynyak TB, Bychkivska Y, Frey MH, Jeffrey KD, Sampaio AV, Underhill TM, Johnson JD. Roles of IP3R and RyR Ca2+ channels in endoplasmic reticulum stress and beta-cell death. Diabetes 2009;58:422-432. [PubMed: 19033399] 
115. Lovis P, Roggli E, Laybutt DR, Gattesco S, Yang JY, Widmann C, Abderrahmani A, Regazzi R. Alterations in microRNA expression contribute to fatty acid-induced pancreatic beta-cell dysfunction. Diabetes 2008;57:2728-2736. [PubMed: 18633110]

116. Richieri GV, Anel A, Kleinfeld AM. Interactions of long-chain fatty acids and albumin: determination of free fatty acid levels using the fluorescent probe ADIFAB. Biochemistry 1993;32:7574-7580. [PubMed: 8338853]

117. Richieri GV, Kleinfeld AM. Unbound free fatty acid levels in human serum. J Lipid Res 1995;36:229-240. [PubMed: 7751810]

118. Cruz WS, Kwon G, Marshall CA, McDaniel ML, Semenkovich CF. Glucose and insulin stimulate heparin-releasable lipoprotein lipase activity in mouse islets and INS-1 cells. A potential link between insulin resistance and beta-cell dysfunction. J Biol Chem 2001;276:12162-12168. [PubMed: 11154699]

119. Pappan KL, Pan Z, Kwon G, Marshall CA, Coleman T, Goldberg IJ, McDaniel ML, Semenkovich CF. Pancreatic beta-cell lipoprotein lipase independently regulates islet glucose metabolism and normal insulin secretion. J Biol Chem 2005;280:9023-9029. [PubMed: 15637076]

120. Unger RH. Minireview: weapons of lean body mass destruction: the role of ectopic lipids in the metabolic syndrome. Endocrinology 2003;144:5159-5165. [PubMed: 12960011]

121. Lee Y, Hirose H, Ohneda M, Johnson JH, McGarry JD, Unger RH. Beta-cell lipotoxicity in the pathogenesis of non-insulin-dependent diabetes mellitus of obese rats: impairment in adipocytebeta-cell relationships. Proc Natl Acad Sci USA 1994;91:10878-10882. [PubMed: 7971976]

122. Aerts JM, Ottenhoff R, Powlson AS, Grefhorst A, van Eijk M, Dubbelhuis PF, Aten J, Kuipers F, Serlie MJ, Wennekes T, Sethi JK, O'Rahilly S, Overkleeft HS. Pharmacological inhibition of glucosylceramide synthase enhances insulin sensitivity. Diabetes 2007;56:1341-1349. [PubMed: 17287460]

123. Holland WL, Brozinick JT, Wang LP, Hawkins ED, Sargent KM, Liu Y, Narra K, Hoehn KL, Knotts TA, Siesky A, Nelson DH, Karathanasis SK, Fontenot GK, Birnbaum MJ, Summers SA. Inhibition of ceramide synthesis ameliorates glucocorticoid-, saturated-fat-, and obesity-induced insulin resistance. Cell Metab 2007;5:167-179. [PubMed: 17339025]

124. Zhao H, Przybylska M, Wu IH, Zhang J, Siegel C, Komarnitsky S, Yew NS, Cheng SH. Inhibiting glycosphingolipid synthesis improves glycemic control and insulin sensitivity in animal models of type 2 diabetes. Diabetes 2007;56:1210-1218. [PubMed: 17470562]

125. Stein DT, Stevenson BE, Chester MW, Basit M, Daniels MB, Turley SD, McGarry JD. The insulinotropic potency of fatty acids is influenced profoundly by their chain length and degree of saturation. J Clin Invest 1997;100:398-403. [PubMed: 9218517]

126. Magnan C, Collins S, Berthault MF, Kassis N, Vincent M, Gilbert M, Penicaud L, Ktorza A, Assimacopoulos-Jeannet F. Lipid infusion lowers sympathetic nervous activity and leads to increased beta-cell responsiveness to glucose. J Clin Invest 1999;103:413-419. [PubMed: 9927503]

127. Steil GM, Trivedi N, Jonas JC, Hasenkamp WM, Sharma A, Bonner-Weir S, Weir GC. Adaptation of beta-cell mass to substrate oversupply: enhanced function with normal gene expression. Am J Physiol Endocrinol Metab 2001;280:E788-796. [PubMed: 11287362]

128. Goh TT, Mason TM, Gupta N, So A, Lam TK, Lam L, Lewis GF, Mari A, Giacca A. Lipid-induced beta-cell dysfunction in vivo in models of progressive beta-cell failure. Am J Physiol Endocrinol Metab 2007;292:E549-560. [PubMed: 17003242]

129. Oprescu AI, Bikopoulos G, Naassan A, Allister EM, Tang C, Park E, Uchino H, Lewis GF, Fantus IG, Rozakis-Adcock M, Wheeler MB, Giacca A. Free fatty acid-induced reduction in glucosestimulated insulin secretion: evidence for a role of oxidative stress in vitro and in vivo. Diabetes 2007;56:2927-2937. [PubMed: 17717282]

130. Rankin MM, Kushner JA. Adaptive beta-cell proliferation is severely restricted with advanced age. Diabetes 2009;58:1365-1372. [PubMed: 19265026]

131. Tschen SI, Dhawan S, Gurlo T, Bhushan A. Age-dependent decline in beta-cell proliferation restricts the capacity of beta-cell regeneration in mice. Diabetes 2009;58:1312-1320. [PubMed: 19228811]

132. Boden G, Chen X, Rosner J, Barton M. Effects of a $48 \mathrm{~h}$ fat infusion on insulin secretion and glucose utilization. Diabetes 1995;44:1239-1242. [PubMed: 7556964] 
133. Boden G, Chen X. Effects of fatty acids and ketone bodies on basal insulin secretion in type 2 diabetes. Diabetes 1999;48:577-583. [PubMed: 10078559]

134. Carpentier A, Mittelman S, Lamarche B, Bergman R, Giacca A, Lewis G. Acute enhancement of insulin secretion by FFA in humans is lost with prolonged FFA elevation. Am J Physiol 1999;276

135. Carpentier A, Giacca A, Lewis GF. Effect of increased plasma non-esterified fatty acids (NEFAs) on arginine-stimulated insulin secretion in obese humans. Diabetologia 2001;44:1989-1997. [PubMed: 11719829]

136. Carpentier A, Mittelman SD, Bergman RN, Giacca A, Lewis GF. Prolonged elevation of plasma free fatty acids impairs pancreatic beta-cell function in obese nondiabetic humans but not in individuals with type 2 diabetes. Diabetes 2000;49:399-408. [PubMed: 10868961]

137. Leung N, Sakaue T, Carpentier A, Uffelman K, Giacca A, Lewis GF. Prolonged increase of plasma non-esterified fatty acids fully abolishes the stimulatory effect of 24 hours of moderate hyperglycaemia on insulin sensitivity and pancreatic beta-cell function in obese men. Diabetologia 2004;47:204-213. [PubMed: 14712348]

138. Xiao C, Giacca A, Carpentier A, Lewis GF. Differential effects of monounsaturated, polyunsaturated and saturated fat ingestion on glucose-stimulated insulin secretion, sensitivity and clearance in overweight and obese, non-diabetic humans. Diabetologia 2006;49:1371-1379. [PubMed: 16596361]

139. Xiao C, Giacca A, Lewis GF. Oral taurine but not N-acetylcysteine ameliorates NEFA-induced impairment in insulin sensitivity and beta cell function in obese and overweight, non-diabetic men. Diabetologia 2008;51:139-146. [PubMed: 18026714]

140. Kashyap S, Belfort R, Gastaldelli A, Pratipanawatr T, Berria R, Pratipanawatr W, Bajaj M, Mandarino L, DeFronzo R, Cusi K. A sustained increase in plasma free fatty acids impairs insulin secretion in nondiabetic subjects genetically predisposed to develop type 2 diabetes. Diabetes 2003;52:2461-2474. [PubMed: 14514628]

141. Cusi K, Kashyap S, Gastaldelli A, Bajaj M, Cersosimo E. Effects on insulin secretion and insulin action of a 48-h reduction of plasma free fatty acids with acipimox in nondiabetic subjects genetically predisposed to type 2 diabetes. Am J Physiol Endocrinol Metab 2007;292:E1775-1781. [PubMed: 17299078]

142. Fex M, Nitert MD, Wierup N, Sundler F, Ling C, Mulder H. Enhanced mitochondrial metabolism may account for the adaptation to insulin resistance in islets from C57BL/6J mice fed a high-fat diet. Diabetologia 2006;50:74-83. [PubMed: 17093947]

143. Nolan CJ, Leahy JL, Delghingaro-Augusto V, Moibi J, Soni K, Peyot ML, Fortier M, Guay C, Lamontagne J, Barbeau A, Przybytkowski E, Joly E, Masiello P, Wang S, Mitchell GA, Prentki M. Beta cell compensation for insulin resistance in Zucker fatty rats: increased lipolysis and fatty acid signalling. Diabetologia 2006;49:2120-2130. [PubMed: 16868750]

144. Leibowitz G, Uckaya G, Oprescu AI, Cerasi E, Gross DJ, Kaiser N. Glucose-regulated proinsulin gene expression is required for adequate insulin production during chronic glucose exposure. Endocrinology 2002;143:3214-3220. [PubMed: 12193532] 


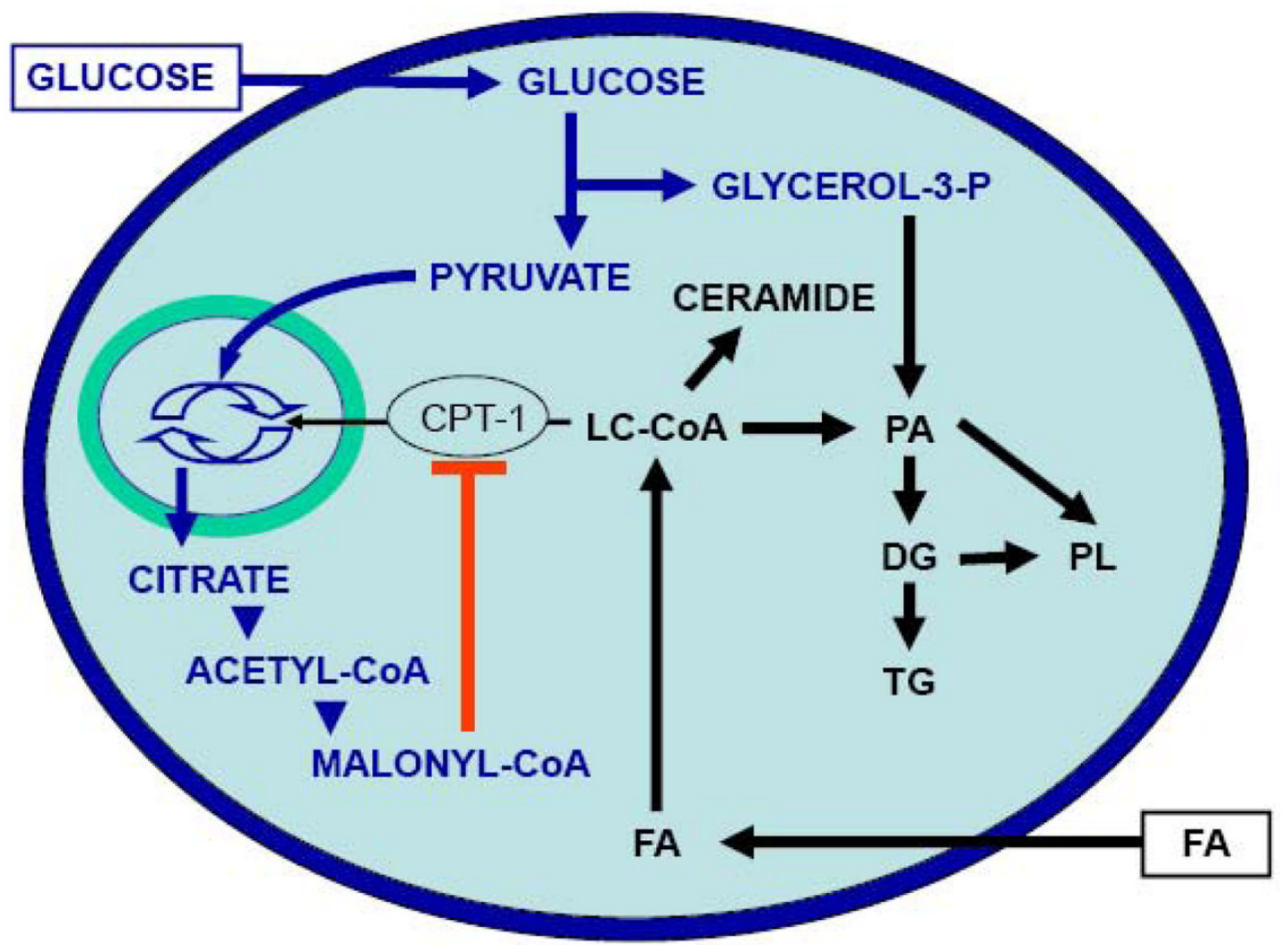

Figure 1. Effects of glucose on lipid partitioning in the beta cell In the presence of simultaneously elevated levels of glucose and fatty-acid (FA), the increase in cytosolic malonyl-CoA resulting from glucose metabolism inhibits the enzyme carnitinepalmitoyl transferase-1 (CPT-1). Transport of long-chain acyl-CoA (LC-CoA) in the mitochondria is reduced, and the esterification pathway is preferentially activated, leading to cytosolic accumulation of lipid-derived signaling molecules such as ceramide, diglycerides (DG), phosphatidic acid (PA), phospholipids (PL), and triglycerides (TG). 


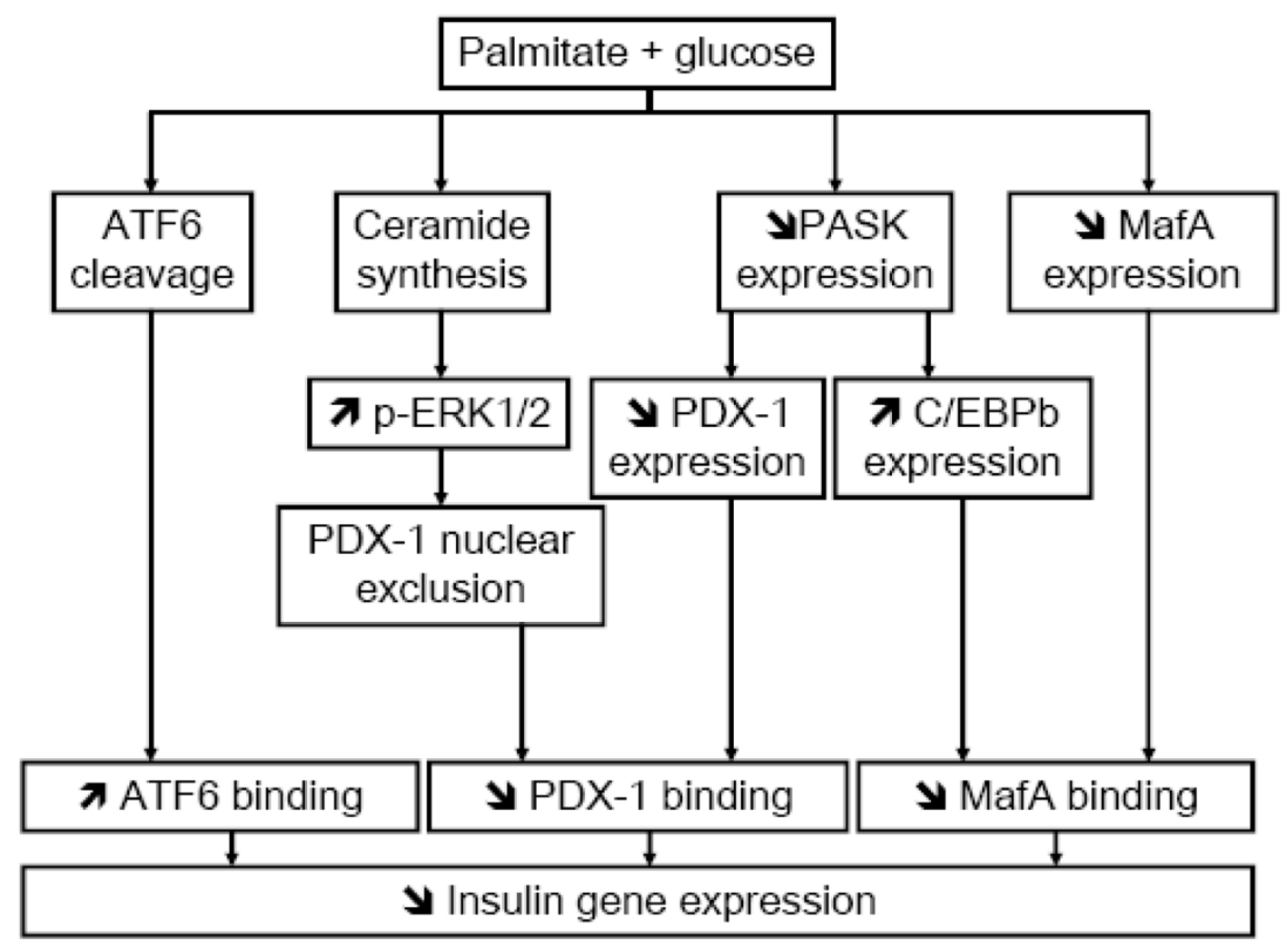

Figure 2. Working model of the mechanisms of fatty-acid inhibition of insulin gene expression Several signaling pathways are activated in beta cells in the presence of simultaneously elevated levels of palmitate and glucose. First, de novo ceramide synthesis [17] leads to sustained activation of ERK 1/2 [82] and exclusion of PDX-1 from the nuclear compartment [18]. Second, palmitate blocks glucose-induction of PASK expression, which results in decreased PDX-1 expression and increased C/EBP $\beta$ expression [82]. Third, palmitate decreases MafA expression [18]. These 3 pathways result in decreased binding activities of PDX-1 and MafA on the insulin promoter. In addition, palmitate induces the cleavage of ATF6, which also represses insulin gene transcription (our unpublished data). 


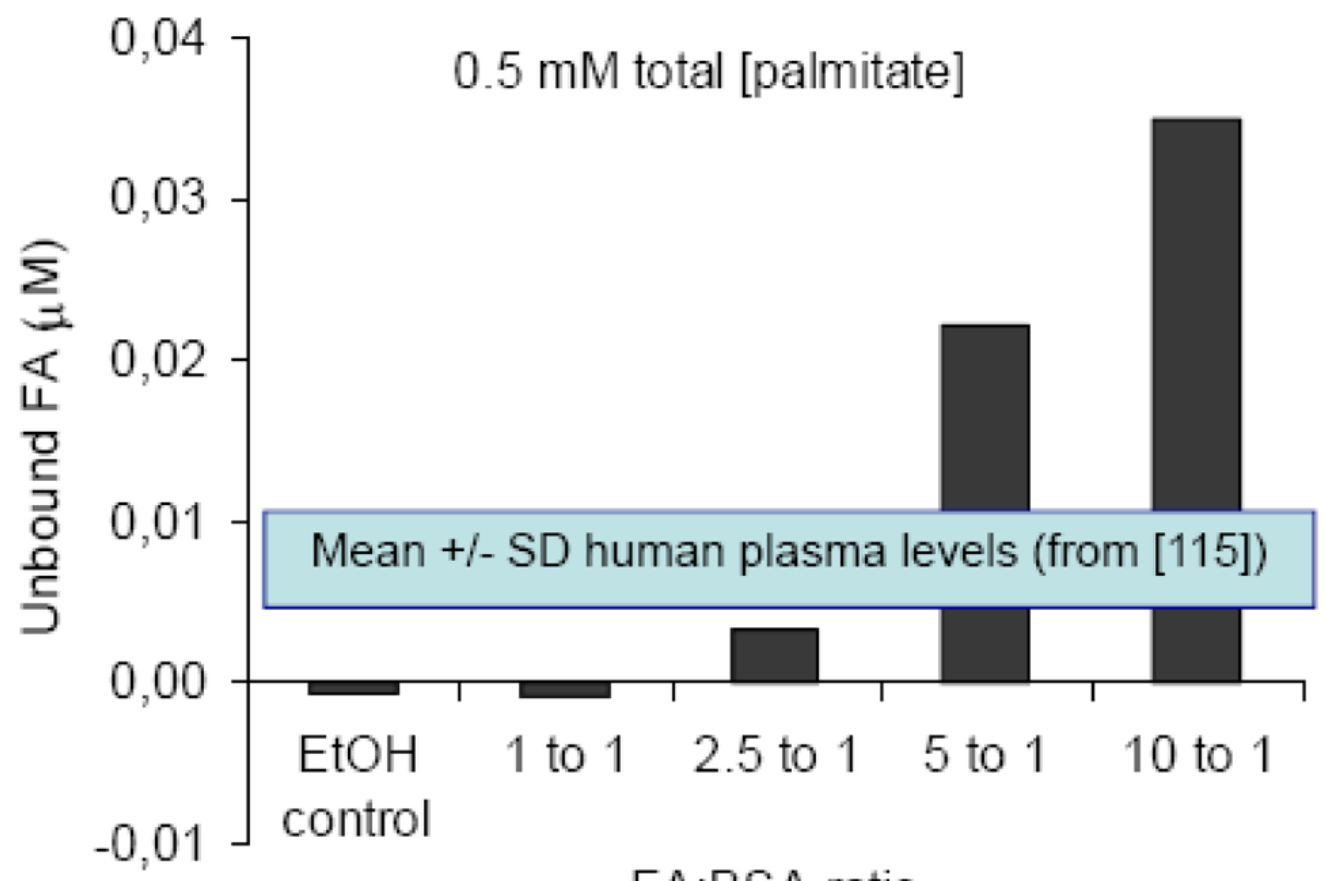

\section{FA:BSA ratio}

Figure 3. Concentrations of unbound fatty acids (FA) in solution as a function of the fatty acid: BSA ratio for a fixed total palmitate concentration of $0.5 \mathrm{mM}$

Unbound fatty acids were measured using the fluorescent probe ADIFAB [114]. Data are the average of 2 independent experiments. Also represented are the mean \pm SD of unbound FA levels measured in human plasma using the same method, from [115]. 


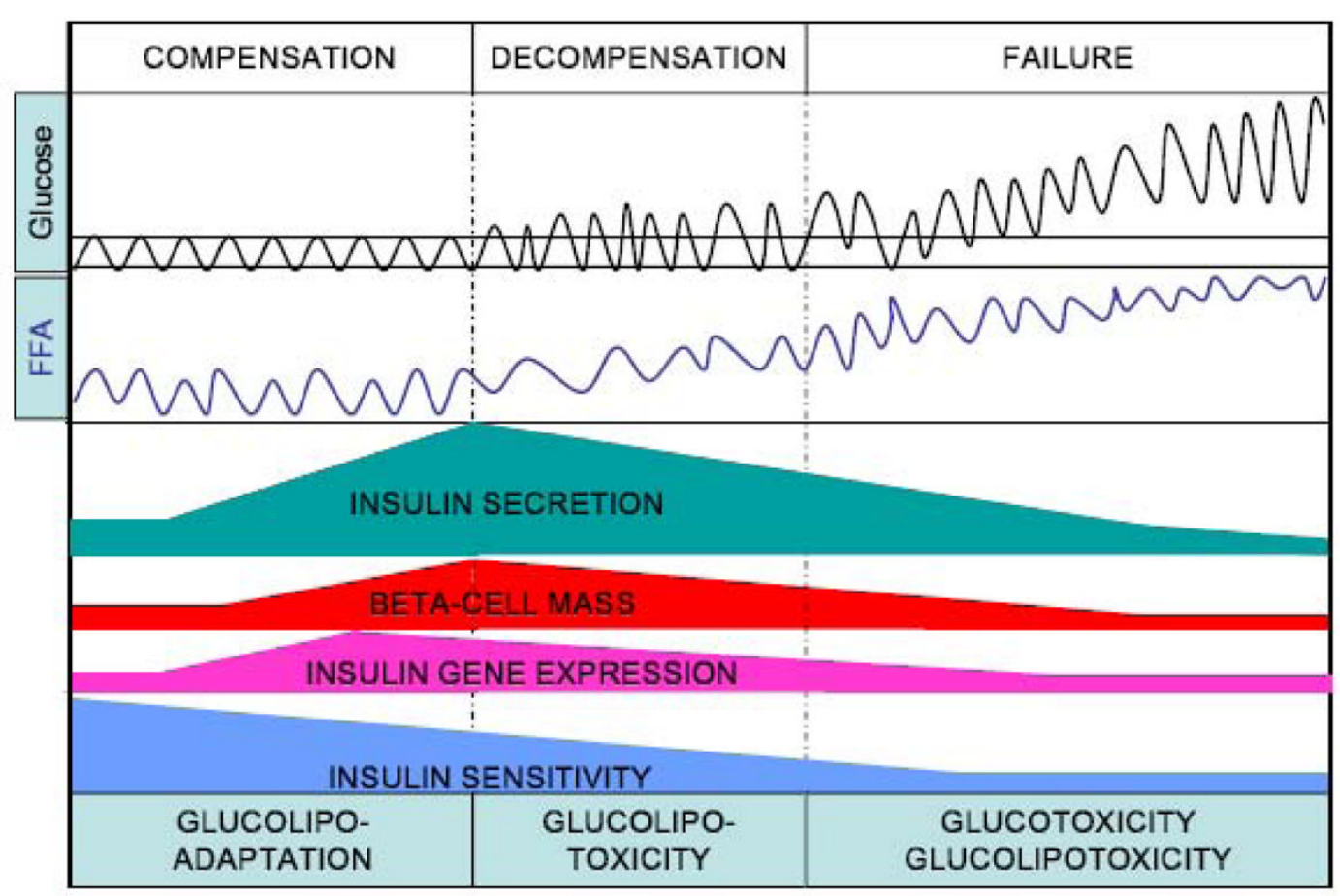

YEARS

Figure 4. Hypothetical representation of the progression from beta-cell compensation to failure in the face of obesity-induced insulin resistance, and the role of glucolipotoxicity

According to this hypothesis, the decrease in insulin sensitivity is initially matched by a marked increase in insulin secretion, insulin gene expression, and beta-cell mass. At this stage the betacell adapts to nutrient oversupply by switching to preferential utilization of fatty acids, as part of the compensatory response (glucolipoadaptation [2]). In genetically predisposed individuals, the beta cell eventually becomes unable to further compensate and glucolipoadaptation evolves towards glucolipotoxicity, in which excursions of blood glucose levels outside of the normal range become permissive for the detrimental effects of elevated fatty acids. This phase is characterized by an early loss of insulin gene expression, decreased insulin secretion (relative to the degree of insulin resistance), and reduced beta-cell mass. Finally, beta-cell failure occurs when glucose levels are permanently in the hyperglycemic range. At that stage both glucotoxicity and glucolipotoxicity contribute to the continued deterioration of beta-cell function. 